\title{
TO THE TOP: THE IMPACT OF DIGITAL TRANSFORMATION ON THE MARKET VALUE OF MAGAZINE LUIZA
}

\author{
RUMO AO TOPO: O IMPACTO DA TRANSFORMAÇÃO DIGITAL NO VALOR DE MERCADO DO MAGAZINE \\ LUIZA
}

HACIA ARRIBA: EL IMPACTO DE LA TRANSFORMACIÓN DIGITAL EN EL VALOR DE MERCADO DE MAGAZINE LUIZA

\section{Guilherme Batistella Castellar \\ Mateus Ferreira Rumbelsperger Querido ${ }^{2}$ \\ Fernando de Souza Meirelles ${ }^{3}$}

\section{Cite as - American Psychological Association (APA)}

Castellar, G. B., Querido, M. F. R., \& Meirelles, F. de S. (2021, Sept./Dec.). To the top: the impact of digital transformation on the market value of Magazine Luiza. International Journal of Innovation - IJI, São Paulo, 9(3), 439-473. https://doi.org/10.5585/iji.v9i3.18621.

\begin{abstract}
Objective of the study: This article aims to highlight the aspects that drove the implementation of digital transformation on Magazine Luiza and contribute to the development of the digital transformation theory.

Relevance/originality: Information technology (IT) offers opportunities for businesses to automatize operations and change business strategies (Henderson \& Venkatraman, 1999), but it is still not clear for every business how to embrace technology (Drnevich \& Croson, 2013).

Methodology/approach: Using a case study, we analyzed the main aspects of the digital transformation of the Brazilian retailer Luiza Magazine, which achieved a 43,000\% increase in its share price between 2015 and 2020, mainly due to innovations enabled by IT.

Main results: We identify that some of the main aspects of the company's digital transformation have not been properly studied in the literature, such as the use of a bimodal IT structure and the use and interconnectivity between traditional and new technologies in innovative and even disruptive ways.

Theoretical/methodological contributions: This study contributes to the literature by analyzing empirical data on the pillars that support the implementation of digital transformation in an organization, which can be used as input to theory development on digital transformation.

Social/management contributions: The digital transformation of Magazine Luiza resulted in a large increase in the market value of the company. This, aligned with the company's expansion and increasingly better results, suggests that technology has the potential to change the company's strategy and lead to its success, corroborating Bharadwaj's (2013) view.
\end{abstract}

Keywords: Digital transformation. Digital business strategy. Bimodal IT. Innovation. Digitalization.

\section{Resumo}

Objetivo do estudo: Destacar os aspectos que impulsionaram a implementação da Transformação Digital no Magazine Luiza e contribuir para o desenvolvimento de teoria sobre Transformação Digital.

\footnotetext{
${ }^{1}$ Master's Degree, FGV EAESP. São Paulo - SP, Brazil. g.batistella.castellar@gmail.com

2 Master's Degree, FGV EAESP. São Paulo - SP, Brazil. mateus.querido@ outlook.com

3 Full Professor, PhD, FGV EAESP. São Paulo - SP, Brazil. fernando.meirelles@fgv.br
} 
Relevância/originalidade: A Tecnologia da Informação (TI) oferece oportunidades para as empresas automatizarem operações e mudar a estratégia do negócio (Henderson \& Venkatraman, 1999), mas ainda não é claro para as empresas sobre como abordar a tecnologia (Drnevich \& Croson, 2013).

Metodologia/abordagem: Analisamos por meio de um estudo de caso os principais aspectos da Transformação Digital da varejista brasileira Magazine Luiza, que alcançou um aumento de $43.000 \%$ no preço das ações entre 2015 e 2020, principalmente devido às inovações possibilitadas pela TI.

Principais resultados: Identificamos que alguns dos principais aspectos da transformação digital da empresa não estão sendo adequadamente estudados na literatura, como o uso de uma estrutura de TI bimodal e o uso e a interconectividade entre tecnologias tradicionais e novas de maneiras inovadoras e até disruptivas.

Contribuições teóricas/metodológicas: Este estudo contribui com a literatura analisando dados empíricos sobre os pilares que sustentam a implementação da Transformação Digital em uma organização, que podem ser usados como insumo para o desenvolvimento de teoria sobre Transformação Digital.

Contribuições sociais/para a gestão: A transformação digital do Magazine Luiza resultou em um grande aumento no valor de mercado da empresa. Isso, alinhado à expansão da empresa e a resultados cada vez melhores, sugere que a tecnologia tem o potencial de mudar a estratégia da empresa e torná-la bem-sucedida, corroborando a visão de Bharadwaj (2013).

Palavras-chave: Transformação digital. Estratégia digital de negócios. TI Bimodal. Inovação. Digitalização.

\section{Resumen}

Objetivo del studio: Este artículo tiene como objetivo resaltar los aspectos que impulsaron la implementación de la Transformación Digital en Magazine Luiza y contribuir al desarrollo de la teoría sobre Transformación Digital.

Originalidad/Relevancia: La tecnología de la información (TI) ofrece oportunidades para que las empresas automaticen las operaciones y cambien la estrategia empresarial (Henderson, JC y Venkatraman, H., 1999), pero no está claro a todas las empresas cómo adoptar la tecnología (Drnevich \& Croson, 2013).

Metodología/enfoque: Analizamos a través de un caso de estudio los principales aspectos de la Transformación Digital en el minorista brasileño Magazine Luiza, que logró un aumento del $43.000 \%$ en el precio de sus acciones entre 2015 y 2020, principalmente debido a las innovaciones habilitadas por TI.

Principales resultados: Identificamos que algunos de los principales aspectos de la Transformación Digital de la empresa no están siendo adecuadamente estudiados en la literatura, como el uso de una estructura de TI bimodal y el uso e interconectividad entre tecnologías tradicionales y nuevas de manera innovadora e incluso disruptiva.

Aportes teóricos/metodológicos: Este estudio contribuye a la literatura mediante el análisis de datos empíricos sobre los pilares que sustentan la implementación de la Transformación Digital en una organización, los cuales pueden ser utilizados como insumo para el desarrollo de la teoría sobre Transformación Digital.

Contribuciones sociales/gestión: La Transformación Digital de Magazine Luiza resultó en un gran incremento en el valor de mercado de la empresa. Esto, alineado con la expansión de la empresa y los resultados cada vez mejores, sugiere que la tecnología tiene el potencial de cambiar la estrategia de la empresa y hacerla exitosa, corroborando la opinión de Bharadwaj (2013).

Palabras clave: Transformación digital. Estrategia empresarial digital. TI bimodal. Innovación. Digitalización. 


\section{Introduction}

The advent of the internet deeply transformed the connectivity among people and companies, and the digital economy changed the way firms in every industry do business, as a significant competitive advantage is achieved from digital innovation and transformation. Digital technologies have been changing the way we use them in every aspect of our lives, be it personal, professional, or societal, and they will continue to evolve. These technologies have been changing rapidly and are becoming more powerful over time, transforming the way organizations grow and doing so in a much faster way than in the past (Demirkan, Spohrer, \& Welser, 2016).

In this context, the evolution of technologies enabled by the combination of information, computing, communication, and connectivity technologies (digital technologies, as defined by Bharadwaj, El Sawy, Pavlou, \& Venkatraman, 2013) has generated strategic responses from companies to adopt and utilize these technologies to gain competitive advantage.

To analyze the strategies applied by companies in the digital age, it is important to first understand the macroambient conditions where digital transformation is happening. Today, we live in a highly connected world where people can access a huge amount of data and make any kind of transaction from practically anywhere, which enables the digitalization of entire companies and their relationship with customers and other organizations in what is called the digital economy. The term digital economy became known through the work of Don Tapscott, The Digital Economy: Promise and Peril in The Age of Networked Intelligence, in which he discussed how the internet would bring monumental changes to the way we live and how companies do business (Tapscott, 1996). Twenty-four years later, some of his predictions have become a reality, while many others were incomplete or incorrect (Tapscott, 2014). However, the environment that Tapscott predicted regarding high interaction between people and organizations through the internet has come to be true.

Many technological advances in information and communication technologies (ICTs) are necessary to enable these changes. Ayres and Williams (2004) illustrate the advances from the microminiaturization of components to the evolution of software and the "rise" of the cell phone. Meirelles (2021) draws upon the spread of computers and mobile devices to show the level of informatization among people and businesses. According to him, the number of devices with access to the internet in Brazil reached two for each inhabitant. This shows the level of connectivity people have to the internet, creating an infrastructure that enables many possibilities for businesses to communicate with customers in more exciting and effective ways. These changes caused deep transformations in some organizations, motivated by the goal of 
gaining competitive advantage by making use of new technologies and the improved connectivity of people and business, a phenomenon that is called digital transformation.

There is a growing interest in the study of digital transformation in academia. In the past seven years, the number of papers published with the keyword "digital transformation" increased at an average rate of $77 \%$ per year (Scopus, 2019), with a total of 486 papers published in 2019. This can be explained by several factors. First, digital transformation is a very diversified phenomenon permeating business in practically every type of industry, from finance (Scardovi, 2017) to health care (Agarwal et al., 2010; Kraus et al., 2021) and automobiles (Winkelhake, Winkelhake, \& Schilgerius, 2018). Second, there are great expectations that digital transformation can improve business performance, which has been corroborated by empirical data: investments in digital transformation are gaining traction at an accelerated pace. In 2019, the projected expenses of companies around the world with technologies and services that enable digital transformation reached $\$ 1.18$ trillion, a $17.9 \%$ increase compared to 2018 (Framingham, 2019). Third, digital transformation is also a subject of study in many fields, for example, management, innovation, marketing, social sciences, and many others. The heterogeneous nature of digital transformation has attracted the attention of researchers with distinct perspectives and interests. Finally, digital transformation has several fronts that can be the object of study, encompassing social media, mobile devices, analytics and big data, cloud computing, digital platforms and ecosystems, the Internet of Things, artificial intelligence (AI), blockchain, and robotics, among other technologies, which can be studied individually or in clusters (Bharadwaj et al., 2013; Ross, 2014; Verhoef et al., 2021).

Digital transformation is a relatively emergent subject in information systems management, and there is still no consensus on the definition of the term. While earlier research suggests that the phenomenon reflects the change in the role of IT from a functional-level strategy to a fusion with the business strategy itself (Bharadwaj et al., 2013), other researchers interpret the phenomenon as a maturity process toward achieving the fusion of IT and the business itself (Soh, Yeow, Goh, \& Hansen, 2019).

However, what changes in practice in the role of an IT department when a company is implementing its digital transformation process may generate some discussion. IT has always implemented systems to automate business processes, so digital transformation is not just the automatization of many business processes, and there have been many advancements in IT infrastructure over time. IT has long been a part of organizations, such as in the processing capabilities of distributed computing and mainframes. Digital transformation is not just the use 
of cloud computing. These aspects only characterize IT as a functional-level strategy and, in many circumstances, as a cost. What is changing in the IT landscape is the maturity the area is obtaining (e.g., computing capacity is higher and cheaper than ever before, there are more IT professionals in number and in specialties and people are more familiar with technology, mainly due to mobile technologies and social media). This maturity that IT has obtained in business and in society offers many opportunities for companies to improve processes, innovate, create new business models, and transform customers' experience using software and hardware, which has always been the core of IT. Therefore, digital transformation is not just the use of software and hardware on a larger scale but can be understood as transformations in business and customer experience enabled using technology on a larger scale. Thus, we can view digital transformation as a robust and accelerated transformation of business activities, processes, competences, and models to fully leverage the changes and opportunities that digital technologies bring (Demirkan, Spohrer \& Welser, 2016)

In Brazil, companies are in different stages of the digital transformation process, and there is no consensus among business leaders on their digital transformation ambition (Dreyfuss, \& Toledo, 2019). Technology does not generate value by itself. When used correctly, it can bring great value for the business and renovate the organization (Bharadwaj, 2000; Nwankpa \& Roumani, 2016), but when that is not the case, it can be very costly to the firm (Bartis \& Mitev, 2008; Olesen \& Myers, 1999). Often, initiatives that do work are those that bring innovation to the business (Gu \& Surendra, 2004). In the retail industry, for example, ICT innovation has driven the largest changes with the digital transformation of companies (Pantano, 2014). There are many types of innovation and stages for achieving it (Fichman, Dos Santos, \& Zheng, 2014); if technology does achieve innovation, there are great chances of success for the company. One way of quantifying this success is by measuring the market value of the company, which is an important indicator of company growth and future perspectives. There are studies in the literature about the relationship between ICT and innovation and the market value of a company (Dos Santos, Peffersv \& Mauer, 1993; Hall, 1999). However, current transformations in the retail market mentioned above present an opportunity for the study of the synergy of these topics and their impact on firm performance, expressed in this article solely as market value growth.

Although there are studies on digital transformation, it is still not clear what the main pillars are that sustain the digital transformation of companies. The research problem, this study addresses how a company can implement a successful digital transformation. To that end, this 
article aims to highlight the main aspects that drive the implementation of digital transformation in a company and, thus, contribute to the development of studies on digital transformation. To do so, we investigated the evolution of digital transformation at Magazine Luiza (a Brazilian department store) from 2011 to 2019, a period where the company had major changes in its operations and administration, experiencing one of the largest stock rallies in Brazilian history. In December 2015, the company stock (MGLU3) was worth R \$ 0,13 (Brazilian reals), but in January 2020 , the stock sold at $\mathrm{R} \$ 56,15$, making the company a good case for studying the impact of IT on the market value of retail companies.

\section{Literature review}

\subsection{Approaches to digitalization}

The rapid changes in the technology landscape have called for responses from organizations (Bharadwaj et al., 2013), and different strategies have emerged. In the literature, we notice two major lines of strategies related to the digital strategy of business: digital transformation and digital optimization (Proctor, Smith, Anderson, \& Sampath, 2019). Digital optimization is defined by Proctor et al. (2019, p. 5). as "the use of digital technologies to improve employee productivity, create a better consumer experience, or increase revenue- and value-producing opportunities". Even though this term is not as in the spotlight as digital transformation, digital optimization is how most organizations embrace digital threats and opportunities (Sia, Soh, \& Weill, 2016). This can be explained by the complexity of factors necessary for a real transformation, which can involve structural changes in leadership, organization, culture, business models, agility, dynamic capabilities, and resistance from employees, among other aspects (Vial, 2019; Nylén \& Holmström, 2015; Karimi \& Walter, 2015). Companies need to define and adjust their digital ambitions accordingly to attain satisfactory results and be resilient to change, respecting the industry leads so they are not disrupted (LeHong \& Waller, 2018).

Digital transformation, on the other hand, can be defined as "a process that aims to improve an entity by triggering significant changes to its properties through combinations of information, computing, communication, and connectivity technologies" (Vial, 2019, p. 118), which is an organizational change that is generated by the widespread use of digital technologies (Hanelt, Bohnsack, Marz \& Antunes, 2021). By applying this process, firms can be more efficient and innovative, generate new business models and improve the customer experience (Sia et al., 2016). The literature also separates the digital transformation process 
according to the perspective on how integrated the IT function is in the business. Bharadwaj et al. (2013) bring attention to the changes companies are facing in this new digital era and the need to change the view of information technology from the functional level to the strategical level in a fusion between IT strategy and business strategy, a phenomenon they named the digital business strategy. Matt, Hess and Benlian (2015, p. 340) propose another perspective where digital transformation comprises the transformational process itself. In their opinion, digital transformation is "a blueprint that supports companies in governing the transformations that arise owing to the integration of digital technologies, as well as in their operations after a transformation", not only the end as proposed by Bharadwaj et al. (2013).

Vial (2019) cautions that a common misunderstanding is that only technology is necessary for the digital transformation of companies, whereas strategy and changes to the organization's structure, process and culture are required as well. The model proposed by Albertin and Albertin (2012) helps to explain how complex a digital transformation can be. The model connects the dimensions that drive IT strategy and explores the relationships between market competitiveness, consumer expectations, IT capabilities, IT governance and firm performance. Given this intricate landscape, companies must stay alert to every aspect that can be impacted by their digital transformation; otherwise, it may be a huge failure (Davenport \& Westerman, 2018).

For example, Piccinini, Gregory and Kolbe (2015) argue that changes in the consumerproducer relationship are drivers of digital transformation, where customers expect more information from businesses in terms of information quality, agility and interaction with organizations, and companies respond by placing the consumer at the center of their operations and offering more customized products and services. Setia, Setia, Venkatesh and Joglekar (2013) analyze how the application of capabilities such as customer orientation (propensity to act) and customer response (ability to act) help firms locally sense and respond to customer needs and wants and improve customer service performance.

Variations in the competitive environment are also an important factor in how the digital strategic posture of companies manifests itself (Mithas, Tafti \& Mitchell, 2013). According to the author, "managers view IT as a platform for undertaking strategic actions in response to actions of industry peers", which can lead to failures in business initiatives due to the lack of anticipation of the reaction of competitors given industry conditions. Cain and Waller (2018) and Gewald et al. (2017) bring attention to the importance of the digital dexterity of the workforce, the ability and desire to use new and existing technology for better business 
outcomes, and its alignment with the digital strategy of the company. Karimi and Walter (2015) draw upon disruptive innovation theory to understand the role of first-order dynamic capabilities (resources, processes, and values) in building digital platform capabilities, which in turn impact the performance of response to digital disruption. Rai and Tang (2014) study the impact of collaborative capabilities, dyadic IT customization and network IT standardization on the execution mechanisms between the strategic intent of interfirm collaboration and the (re)configuration of business models to enable different sources of value creation and appropriation. Yoo, Henfridsson and Lyytinen (2010) propose a layered modular architecture, extending the modular architecture of physical products by incorporating loosely coupled layers of devices, networks, services, and contents created by digital technology and describe the emerging organizing logic of digital innovation. Horlach, Drews and Schirmer (2016) and Haffke, Kalgovas and Benlian (2017) describe the segregation of IT into two modes (traditional and agile) — a process named bimodal IT - to support flexibility, agility, and innovative uses of IT in a digital business context while still maintaining the stability required from IT systems. All these dimensions and their relationships need to be considered when a firm is implementing its digital transformation.

It is also important to note that digital transformation is not an instantaneous process, but rather there are phases in the process, as illustrated in the research of Berghaus and Back (2016). Hill and Govekar (2019) complement this approach by explaining the importance of adequate indicators to measure the evolution of the digital value delivered and the challenges in defining these indicators.

Many frameworks for the digital transformation of companies have been proposed in the literature. Nwaiwu (2018) compares ten different conceptual models on what aspects of the company the model acts on and how it acts on those aspects. Vial (2019) proposes a framework (Figure 1) based on a cycle where the use of digital technologies fuels disruptions that triggers strategic responses from firms, which, in turn, amplifies the use of digital technologies. This cycle enables changes in the value creation paths and generates positive and negative impacts for the business. 


\section{Figure 1}

\section{Building blocks of the digital transformation process}

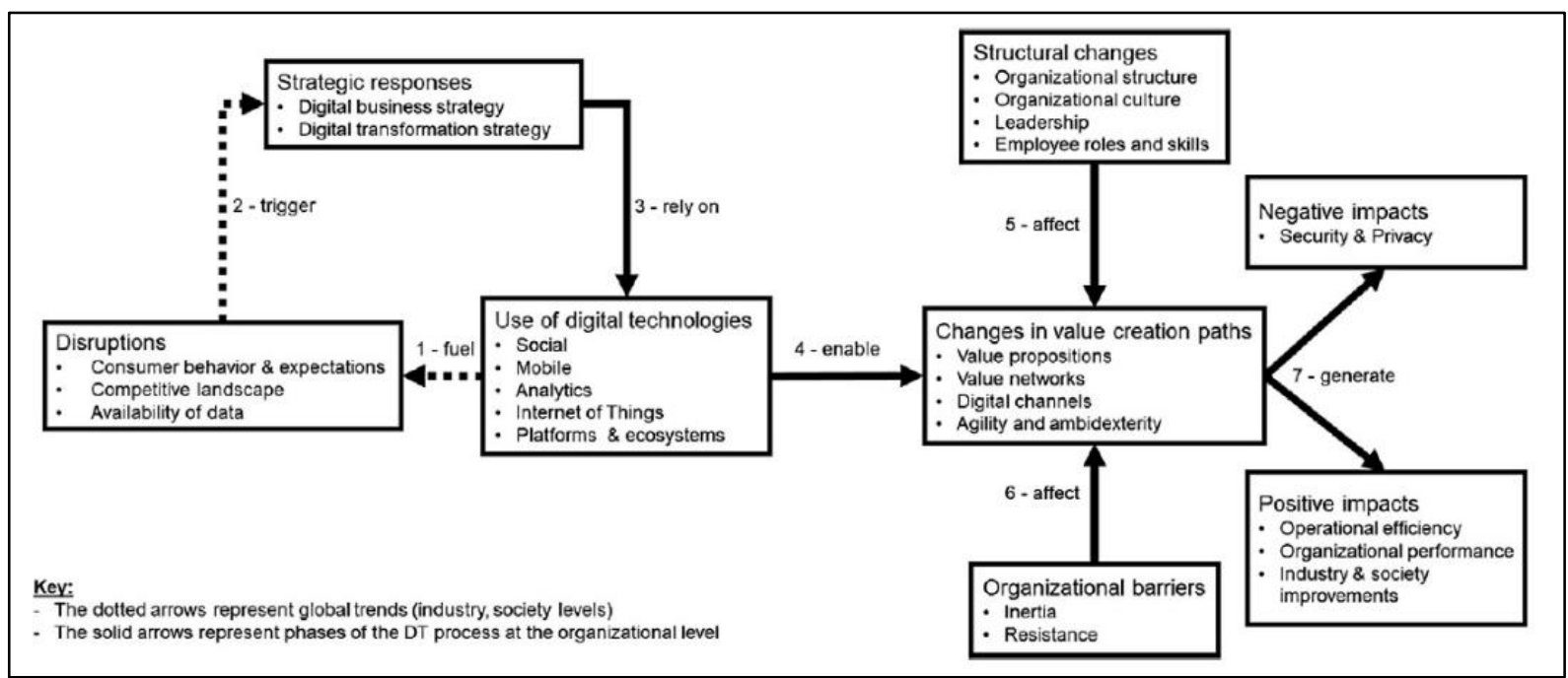

Source: Vial (2019).

\subsection{Digital innovation}

Organizations of all sizes have started to reevaluate their products and services in an attempt to develop and achieve an innovation culture (Hidalgo \& Albors, 2008).

Hidalgo and Albors (2008) use Schumpeter's definition (Schumpeter, 1934) for innovation as being a new combination of productive resources, where the author defines 5 components of innovation: (i) introduction of new products, (ii) new production methods, (iii) exploration of new markets, (iv) conquering of new resources of supply and (v) new ways of organizing the business. In these terms, innovation is not the result of individual actions but rather encompasses (a) problem solving, (b) relationships between firms, (c) diversity of learning, (d) exchange of codified and tacit knowledge and (e) interactive processes that generate an innovative system or innovation cluster.

Adams, Bessant, and Phelps (2006) indicate that the term "innovation" is quite ambiguous and can lead us to a lack of knowledge on this matter. In this context, the authors define innovation as the successful exploitation of new ideas once it aggregates products, services, administration, processes, and technology all in one.

Considering the digital transformation perspective, Hinings, Gegenhuber and Greenwood (2018) consider the usage of digital innovation to be the usage of digital technologies in a wide range of innovations.

Nambisan et al. (2017, p. 224) conceptualize digital innovation as: 
"[.] the creation of (and consequent change in) market offerings, business processes, or models that result from the use of digital technology. Stated differently, in digital innovation, digital technologies and associated digitizing processes form an innate part of the new idea and/or its development, diffusion, or assimilation. Given the above conceptualization, digital innovation management refers to the practices, processes, and principles that underlie the effective orchestration of digital innovation".

They consider their definition within a range of outcomes, such as products, platforms, services, customer experience and other values, if it involves digital technologies and digitized processes; however, the outcome does not necessarily need to be digital. It also involves tools and infrastructure to make the innovation possible and ensures that the outcomes may be diffused, assimilated, or adapted to every context in which it might be applied, considering a digital environment.

From the institutional perspective, digital innovation is how the company enables its arrangements to emerge and be diffused through the entire organization and its fields in digital form. It emphasizes changing existing sets to new ones, striving for legitimacy (Hinings, Gegenhuber \& Greenwood, 2018). The authors affirm that one form of digital innovation produces new organizational forms; however, one form that is suitable to a certain organization might not be suitable to another (vom Brocke et al., 2017). It also requires building infrastructures that go beyond solely the innovation and organization itself; it must link different actors, provide governance and regulation, and establish legitimacy for its actions (Hinings, Gegenhuber \& Greenwood, 2018).

In the next sections, we present how Magazine Luiza took advantage of digital transformation and provided disruptive technologies in an innovative manner to achieve a remarkable increase in its market value through the usage of information technology.

\section{Methodology}

To analyze how digital transformation was implemented in Luiza Magazine, an embedded case study methodology was utilized (Yin, 2017). According to Yin, case studies are relevant when one wants to explain how a social phenomenon occurs. Additionally, the essence of case studies is that they illuminate a decision or a group of decisions: why they were made, how were they implemented and what results they generated (Schramm, 1971). An exploratory approach has been adopted in this study based on a single-case model with multiple subunits of analysis (Yin, 2017). Usually, a case study is performed by observation, interviews and questioning, collecting data aimed at understanding the dynamics in the research configuration (Eisenhardt, 1989). This approach enables a better understanding of how firms can implement 
their digital transformation through the lens of theoretical analysis and strategic frameworks in the literature. The use of an embedded case study permits a broad understanding of the many aspects involved in a company's digital transformation implementation and their relationship, as opposed to a holistic case study, e.g., analyzing only one aspect of a company's digitalization.

Magazine Luiza is suited for our analysis of how firms apply digital transformation strategies in practice for two reasons. First, it achieved a great increase in market value due to its digital transformation, according to specialists from the financial markets and executives from the company (Madureira, 2019; Folha de São Paulo, 2019), which is a strong indicator of the company's success. Second, there is a high volume of information from the company that is publicly available on the internet, such as prior academic studies, detailed administrative reports and interviews with members of the company's executive board.

\subsection{Data collection}

The data utilized in this study were gathered from publicly available sources. As mentioned above, there is much information available online, which allows for more agility and abundance of data in reaching the study's objective. However, as Hox and Boeije (2005) explain, researchers need to carefully evaluate the available information and work with data that address the study's research problem.

With this direction in mind, we collected the data according to four groups and based on their relevance to the study's purpose. First, we listed the available information on Magazine Luiza's website, such as administrative reports, general presentations, and letters to shareholders, totaling 69 presentations. Second, we collected one interview with Magazine Luiza's CEO, Frederico Trajano. Then, we gathered articles from 13 known newspapers in Brazil to obtain a more independent view of the company's transformation, totaling 59 articles. The articles were searched in Google News with the keyword "Luiza Magazine" and filtered by year from 2011 to 2019. Finally, we collected a case of the application of a chatbot in Luiza Magazine.

We opted to choose the period between 2011 and 2019 for our study for two main reasons. First, 2011 was the year that Magazine Luiza made its IPO and started publishing administrative reports about its operations. Second, this period represents the beginning of the digital transformation to the present time, when the company is still evolving in its digitalization process. 


\subsection{Data analysis}

To analyze the collected data, we utilized a chronological analysis of the events, which made it possible to arrange all the data gathered in a comprehensive form. Starting with the administrative reports, we draw a timeline with the evolution of events from 2011 to 2019 . The frameworks and studies on digital transformation available in the literature gave the direction to select the most relevant aspects of Magazine Luiza's transformation from all the data. From a total of 69 administrative reports, we selected 21, as many administrative reports from the same year had the same information. Then, we analyzed the newspaper articles, cases, and interviews to consolidate our analysis. From a total of 59 newspaper articles, we utilized 10, which had information that was relevant for our study. We also utilized the selected case and interview.

Even though there were a vast amount of financial data from the company in the collected material, we did not elaborate on this information since the focus of this study is to analyze the technological aspects of the company's transformation. Figure 2 provides a framework on how the data analysis was performed in this research.

\section{Figure 2}

Case study framework

\begin{tabular}{|c|c|c|c|}
\hline $\begin{array}{c}\text { Purpose of Case } \\
\text { Study }\end{array}$ & $\begin{array}{c}\text { Exploratory Case } \\
\text { Study }\end{array}$ & $\begin{array}{l}\text { Gathered Data } \\
\text { Administrative }\end{array}$ & Data Analysis \\
\hline $\begin{array}{l}\text { Provide insights for } \\
\text { the study of Digital } \\
\text { Transformation }\end{array}$ & $\begin{array}{l}\text { Exploration of digital } \\
\text { transformation on a } \\
\text { retail company }\end{array}$ & $\begin{array}{c}\text { Reports + Published } \\
\text { Interviews }+ \\
\text { Newspaper articles }\end{array}$ & Explanation Building \\
\hline
\end{tabular}

Source: Adapted from Ebneyamini and Sadeghi (2018).

\section{Results}

In this section, we describe the digital transformation process in Magazine Luiza through the period from 2011 to 2019, divided into two parts: the first compromising the years before the digital transformation (2011 to 2014) and the second corresponding to the digital transformation period (from 2015 to 2019). 


\subsection{Before the digital transformation}

Several aspects were critical for Magazine Luiza's digital transformation. Although the company was not aiming for a digital transformation from the beginning, evidence suggests that it knew innovation was important to remain competitive, and the innovations and innovative culture of the company were the basis for its digital transformation.

Back in 2011, when the company made its Initial Public Offering in the Brazilian stock exchange (Kahil, 2011), it already had implemented some digital initiatives, but they were still in the early stages. The main pillar was known as the multichannel model, which was the integration of the sales platform: traditional stores, virtual stores (explained below), websites and tele sales (Magazine Luiza, 2011). The multichannel model allowed many initiatives to be created by the company later. The virtual stores were an initiative that demonstrated the innovative character of the company, created in 1992; they were smaller than conventional stores ( 5 to 7 times smaller) and did not have any inventory, the products were shown to customers in computers or in product catalogs and, when a sale was made, the product was delivered to the customer from distribution centers. This allowed the location of stores in smaller cities without incurring great costs (Magazine Luiza, 2011).

In 2011, the company website had only 27,000 SKUs (Stock Keeping Unit). Another noticeable aspect was the historical archive the company kept of customers' purchases for more than 10 years (Magazine Luiza, 2011), which later became a Big Data project known as Bob.

In 2012, the company launched one of its most remarkable initiatives, the digital character known as Lu (Magazine Luiza, 2012a). Lu was a graphic computer character designed to explain to customers the product characteristics, making technological products more accessible. Frederico Trajano, son of the company president Luiza Heleno Trajano, and who, years later, would become the company CEO, explained that they came up with the idea through the attention they paid to the customer relationship, characteristic of the firm; they were able to take this aspect present in the physical stores to the digital world (Santos, 2016). Lu later became the brand of the company and a symbol of its digital identity.

Another featured innovation in 2012 was a social e-commerce initiative called Magazine You, which allowed any person to sell up to 60 Magazine Luiza's products to friends in Facebook and Orkut, with a commission of 2,5 to 4,5\%. Magazine Luiza was responsible for the operations and delivery of the products, and it was not necessary for any investment from the users (Magazine Luiza, 2012b). The project took a year to be completed and was created in partnership with Facebook and Google (Mello, 2011). The public acceptance was good; there 
were more than 25,000 stores opened after the first three weeks and 70,000 by the end of the year, with a conversion rate (products bought by the number of searches) $50 \%$ higher than the company's website (Magazine Luiza, 2012a, Magazine Luiza, 2012c).

In the same year, the company also launched a mobile sales application (Magazine Luiza, 2012a) and started the multichannel project, a predecessor to the multichannel model whose objective was to make it possible for purchases made in e-commerce to be delivered by the nearest distribution center (Magazine Luiza, 2012a). The multichannel model also made possible the availability of products in the entirety of the national territory (even places where there were no physical stores), facilitated the purchase of any product in any channel the customer wanted, retained customers, unified marketing tools, and reduced fixed costs (Magazine Luiza, 2012a). Another initiative implemented was cloud computing, ensuring the data transfer capability during sales peaks and reducing IT infrastructure costs (Magazine Luiza, 2012c).

Even though there were initiatives in digital transformation, there was not a global project encompassing them or a company strategy in digital transformation, and the innovations remained isolated. Neither were the financial results of the company good; the company had an R\$ 6.7 million loss despite the increase in internet sales (Magazine Luiza, 2012d).

In 2013, an innovation lab was created, known as Luiz Labs. It was dedicated to the research and development of technology, and initially, the lab was an exploratory initiative, as stated in the Annual Report: "We make tests internally with games and develop our own apps to see what we can do and how far we can go" (Magazine Luiza, 2013a). In the following years, the lab would grow to become a central point in Magazine Luiza's digital transformation strategy. In the same year, the company started Bob, a Big Data platform, to make product recommendations to customers on the website and in physical stores. The project was created using historical data aligned with data from Magazine You, which captured information about customer connections and enabled a better understanding of their behavior (Magazine Luiza, 2013a). Magazine Luiza also acquired a cosmetic products website (Época Cosméticos) as a part of its strategy to diversify operations and intensify internet sales (Olivon, 2013) and designed a website directed to people who were engaged, known as "Quero de Casamento" (Magazine Luiza, 2013a). The latter was integrated with Facebook, making it easier for the bride and groom to invite their guests and create virtual photo albums. Additionally, Magazine You was released in a mobile version and was in 170,000 stores by the end of the year 
(Magazine Luiza, 2013a). In 2013, the company had better financial results, with a 113 million Brazilian reals profit (Magazine Luiza, 2013b).

Few significant improvements were identified in 2014. Bob became responsible for all product recommendations on Magazine Luiza's website; it was used in delivery, buying recommendations through email and social networks and personalized marketing on Facebook and Google (Magazine Luiza, 2014a). Luiz Labs launched two projects: Lu's Club and the Mobile Sales app, the former being a portal with daily offers and the latter a mobile app to support salespeople in physical stores, making the purchasing process faster for customers (Magazine Luiza, 2014b). Three projects were developed by Luiz Labs (Magazine Luiza, 2014b). Related to the multichannel model, online sales started to be delivered from only one of the eight company distribution centers to all distribution centers, aiming to reduce delivery time by up to $70 \%$ (Kojikovski, 2014).

Although there was not a publicly announced digital strategy yet, it could be observed that the company was alert to the importance of digital evolution, as stated in the board report: "We are aware of the fast digital evolution that is impacting customers in many economic sectors, and we are alert to the main trends in the world". In the same report, the company also talked about the importance of innovation and Luiz Labs (Magazine Luiza, 2014b).

Even with the attention to the importance of digital technology in the business, the company still had problems related to IT; on Black Friday, for example, the company website was under maintenance at dawn (iG São Paulo, 2014). Financially, the company had a 128 million Brazilian reals profit throughout the year (Magazine Luiza, 2014b).

\subsection{The digital transformation}

2015 was a game changer for the company. The CEO, Luiza Heleno Trajano, was succeeded by her son, Frederico Trajano, who was head of Operations. With Frederico in charge of the company, Magazine Luiza started a new phase: The Digital Transformation Cycle, with the objective of going from a "traditional retail company with a digital platform to a digital company, with physical points of sale and human support" (Magazine Luiza, 2015a). A new strategy was developed to embrace digital transformation on five fronts: multichannel, digital inclusion, physical store digitalization, transformation of the website into a digital platform and digital culture (Magazine Luiza, 2015a).

The multichannel model was advanced: all the mix of products available in ecommerce would be available to digital stores, and more than half of the online sales were being 
delivered by the nearest distribution center. The multichannel model was structured in four pillars (Magazine Luiza, 2015b):

Logistics -9 distribution centers with preestablished routes,

Commercial - online sales with replacement in physical stores,

Operational - sales in physical stores of online items, and

Technological - sales made online and picked up in a physical store.

Digital inclusion, the second front in the company strategy, refers to the mission of "bringing to many what is a privilege of the few" by inviting and teaching customers how to use technology. The main example in this pillar is $\mathrm{Lu}$, the digital character that is used in the digital media of the company, with more than 100,000 subscribers in YouTube and 105 million videos watched (Magazine Luiza, 2015c).

Physical Stores Digitalization included projects developed by Luiz Labs, such as Mobile Sales, Mobile Stockist and Mobile Assemblers. Mobile Sales reduced the buying time from 40 to 4 minutes (Magazine Luiza, 2015c) and implemented improvements through receiving the barcode reader, buying cart, voice product search and a simulator (Magazine Luiza, 2015d). Mobile Stockist is an app that makes the pick-up time shorter in physical stores and Mobile Assembler is an app designed to make the assembling line faster by eliminating administrative tasks (Magazine Luiza, 2015a).

The transformation of the website into a digital platform was a project expected for 2016 that consisted of the sale of third-party products on Magazine Luiza's website, largely amplifying the product portfolio offered. The company started the project by selling products from Época Cosméticos (Magazine Luiza, 2015a).

Finally, the Digital Culture front focused on innovation, speed, and people, with the main example being Luiz Labs, which was composed of 75 software engineers by the end of 2015 (Magazine Luiza, 2015a).

Cloud computing also made advances. One of the main projects in the IT area was the migration of systems hosted in physical data centers to the cloud, known as the Luiza Cloud, making the systems more flexible and agile (Magazine Luiza, 2015b). Magazine You, by the end of 2015, had approximately 100,000 stores (Magazine Luiza, 2015c).

Even though the company had a major transformation strategically, the financial results were not good; the company had a 65 million Brazilian real loss during the year (Magazine Luiza, 2015a), and the share price hit the lowest price in company history, R\$ 0.12 (ADVFN, 2020). Luiza Helena Trajano, who was named president of the company's board of directors, 
announced that the company could be delisted from the stock exchange (Reuters, 2015), but there were no official announcements from the company about the matter.

The digital transformation strategy was intensified in 2016. The Multichannel Model now provided administrative, logistics and sales cost reductions by unifying channels and enabling projects such as Store Pickup (the picking up of products bought online in physical stores); the Digital Culture was highly emphasized in the board's annual report (Magazine Luiza, 2016a) and Luiz Labs had now more than 250 engineers (Magazine Luiza, 2016b). The digitalization of physical stores now included the Mobile Pin Pad that allowed customers to pay for the products on their phones and avoid checkout lines; there was free Wi-Fi access for clients in the stores and Lu Connects, a pack of services for customers phones (antivirus, access to WiFi points distributed all over Brazil and cloud storage)(Magazine Luiza, 2016a), and the transformation of the website in a digital platform now grouped Magazine You, Telesales, Época Cosméticos, Quero de Casamento and Lu's Club (Magazine Luiza, 2016c). But the most noticeable change was the start of the Marketplace, in which the company opened its website for partners to sell their products; over 200 partners had already been included and approximately 400 thousand SKUs were available (Magazine Luiza, 2016b). Digital inclusion was also highlighted in the board's report, concerning the opportunity for the Brazilian population to become more connected (Magazine Luiza, 2016a). The financial results in 2016 were impressive, with an 86 million Brazilian reals profit, despite that year being Brazil's worst recession in history (Magazine Luiza, 2016a; Capucci \& Castro, 2017).

In 2017, the company announced that it was becoming a tech company, with the multichannel model and Luiza Labs as the main pillars of its digital transformation (Magazine Luiza, 2017a). In relation to the multichannel model, the marketplace grew to 750 partners and 1.5 million SKUs (a 375\% increase compared to 2016, even though $30 \%$ of partner requests were denied due to poor service level - Magazine Luiza, 2017a), the buy online and in-store pickup was well received by the customers, with more than $20 \%$ of total sales made in the ecommerce space delivered this way, and Magazine You reached up to 200,000 sellers (Magazine Luiza, 2017a). Luiza Labs was also growing very fast, with more than 450 engineers, almost twice its the year before and representing 30\% of the company payroll (Magazine Luiza, 2017b). Luiza Labs delivered more than 200 projects in 2017, digitalizing the back office and logistics operations and improving the company's mobile applications (internal and external), as specified in Magazine Luiza (2017b). The technology in Magazine Luiza was structured in a bimodal model, where part of the IT team was dedicated to supporting missions and part of 
the team to business missions, as the CTO André Fatala presented in Magazine Luiza day, an annual event of the company (see Figure 4). A highlighted aspect of the IT strategy was the use of APIs to create a business ecosystem with partners and suppliers. In 2015, there were 263 million API calls on Black Friday (a day known for large discounts across the retail industry and a high volume of transactions). Two years later, the number of API calls on the same day rose to more than 1 billion, a 380\% increase (Magazine Luiza, 2017c). Additionally, in 2017, the company was recognized for having the best chatbot in services from Bots Brazil Awards (Nama, 2018). No information about the implementation of the chatbot was found.

In 2018, the company announced that its digital transformation had been completed (Magazine Luiza, 2018a). The company numbers kept growing, 2 new distribution centers were inaugurated (a 20\% increase compared to 2017), 30\% of the e-commerce deliveries in 150 selected cities were made in up to $48 \mathrm{~h}$, the buy online and in-store pickup as a percentage of total e-commerce sales rose to $32 \%, 52 \%$ of total firm sales were made online, and the physical stores were becoming technological shopping and distribution centers (Magazine Luiza, 2018a). In Luiza Labs, which now had 707 employees, new projects were developed, and customers could track their purchases through WhatsApp (a popular instant messaging app in Brazil). Research products used Google Assistant, Bob began making recommendations in Mobile Sales, Neuman, a project to compare algorithms that predict demand, was developed and API calls reached more than 18 billion calls per month (record API calls in November of 2018), as stated in Magazine Luiza (2018a). The company strategy was now directed to the use of APIs to create a platform, an ecosystem increasing collaboration with other companies (Magazine Luiza, 2018b).

2019 was the year the company consolidated and expanded the initiatives from its digital transformation. The company was in an omnichannel model and was working to evolve into a digital ecosystem for retail, with the integration of sellers in its marketplace and through collaboration with partners using APIs. E-commerce sales reached 50\% of the company's total sales, but the company continued to expand the number of physical stores, with more than 150 stores opening in 2019 (Magazine Luiza, 2019). The strategic drivers for the evolution involved five fronts: the exponential growth of the marketplace; the sales of new categories such as food, tires and other items; the evolution of the app to a super app, with other apps inside such as Netshoes (a sports e-commerce company acquired by Magazine Luiza in 2019), Época Cosméticos and Zattini (a fashion e-commerce business also acquired by Magazine Luiza in 2019); the faster delivery of items bought online, with $66 \%$ of the sales delivered in up to two 
days; and Magalu as a Service, a platform to digitalize and connect the retail ecosystem. In 2019, the company reached a total of 24 billion Brazilian Reals in sales, 24 million clients, 20 million app installations, 1,100 physical stores, 17 distribution centers and over 12.3 million different items available in e-commerce (Magazine Luiza, 2019). Luiza Labs had 1,196 collaborators, with the super app plus seven apps (mobile sales, mobile payments, credit digitalization, mobile results, mobile stockist, mobile delivery, and mobile assembler), as in Magazine Luiza (2019).

\subsection{Pillars in the implementation of digital transformation}

\section{Figure 3}

\section{Magazine Luiza digital transformation pillars}

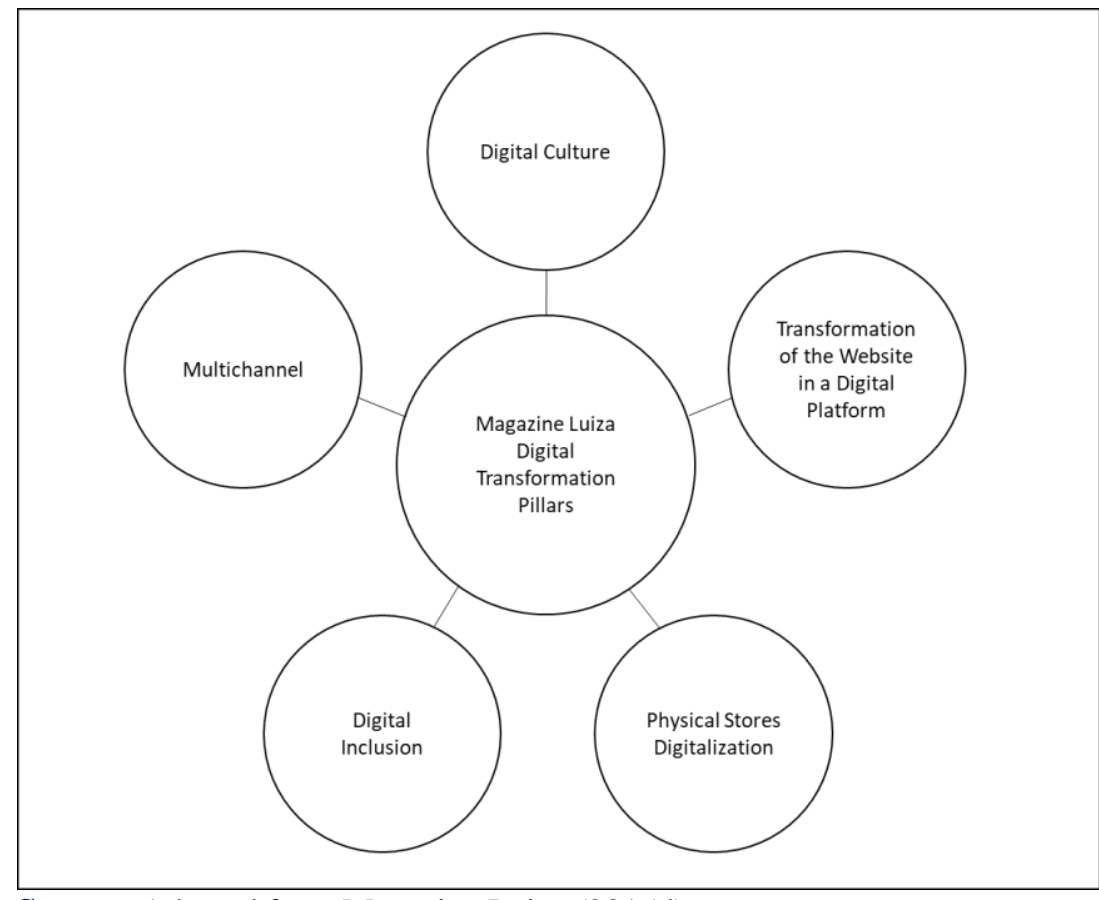

Source: Adapted from Magazine Luiza (2015d).

Culture became a pillar in Magazine Luiza's strategy (see Figure 3), demonstrating the value of this aspect, which was perhaps the most important dimension of the digital transformation process. As Mithas, Tafti and Mitchell (2013) conclude, managers view IT as a platform for undertaking strategic actions in response to the actions of industry peers. However, in Luiza Magazine, IT and innovation were important for the company, which was illustrated by the creation of virtual stores, the multichannel model, the creation of Luiza Labs and digital initiatives such as the apps created by Luiza Labs. The creation of Luiza Labs, in particular, 
was an application of bimodal IT (Horlach et al., 2016), where part of the IT staff stopped working on supporting operational tasks and focused on digital initiatives.

\section{Figure 4}

\section{Bimodal technology structure in Luiza Magazine}

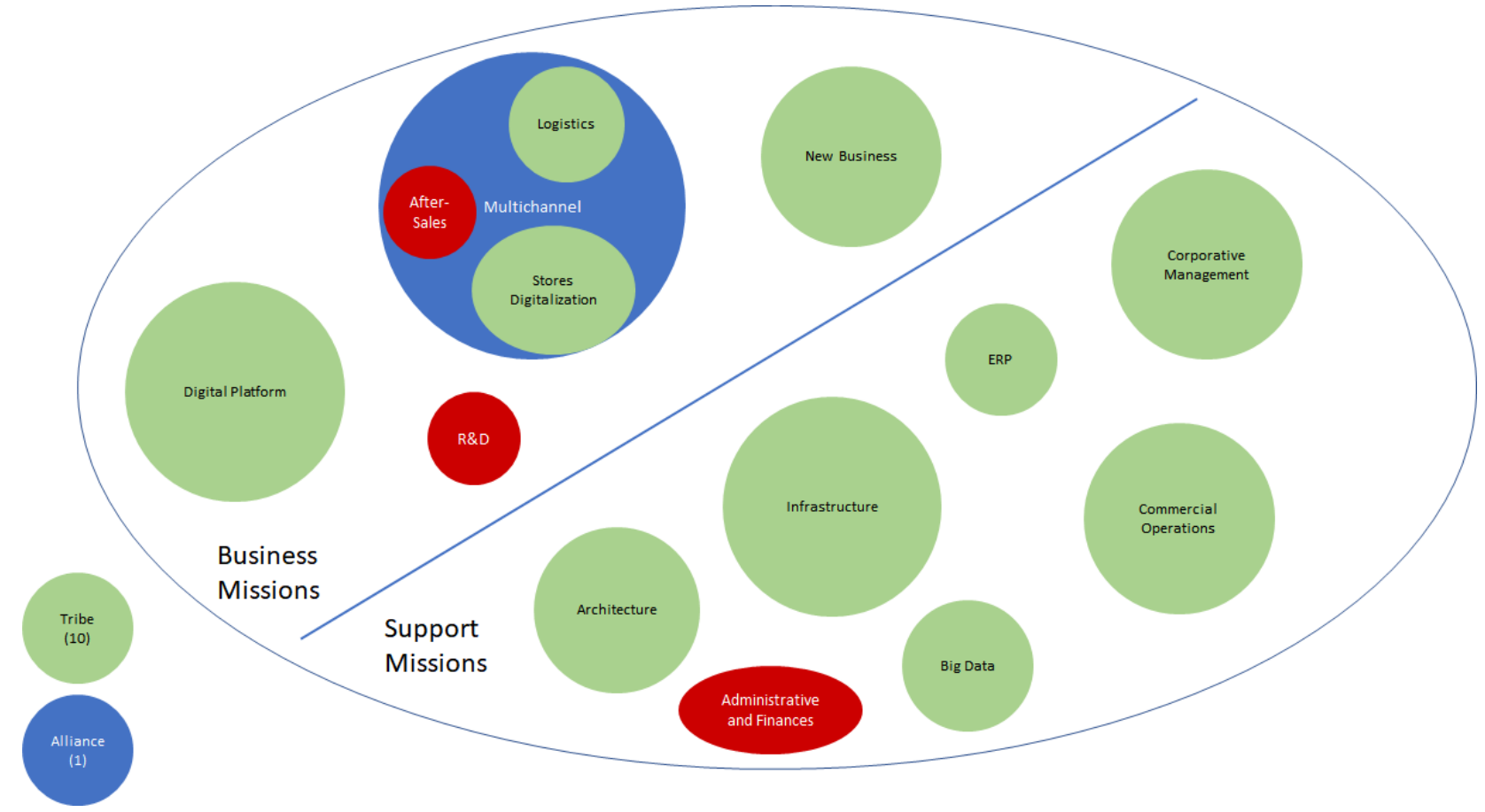

Source: Adapted from Magazine Luiza (2017c).

This enables the development of projects that would otherwise not be a priority for the IT area and would probably be lost among operational support tasks. Andre Fatala, who was involved in the creation of Luiza Labs and later became CTO, was a protagonist in the digital transformation, with innovative ideas and always looking forward to new technologies. Mr. Fatala participated in many of the company's digital initiatives and demonstrated a high degree of digital dexterity (Cain \& Waller, 2018). The combination of the innovative profile of the company, its structure with the creation of Luiza Labs, and people, such as Mr. Fatala, was critical for the digital transformation of Luiza Magazine. 


\section{Figure 5}

Magazine Luiza's digital transformation timeline

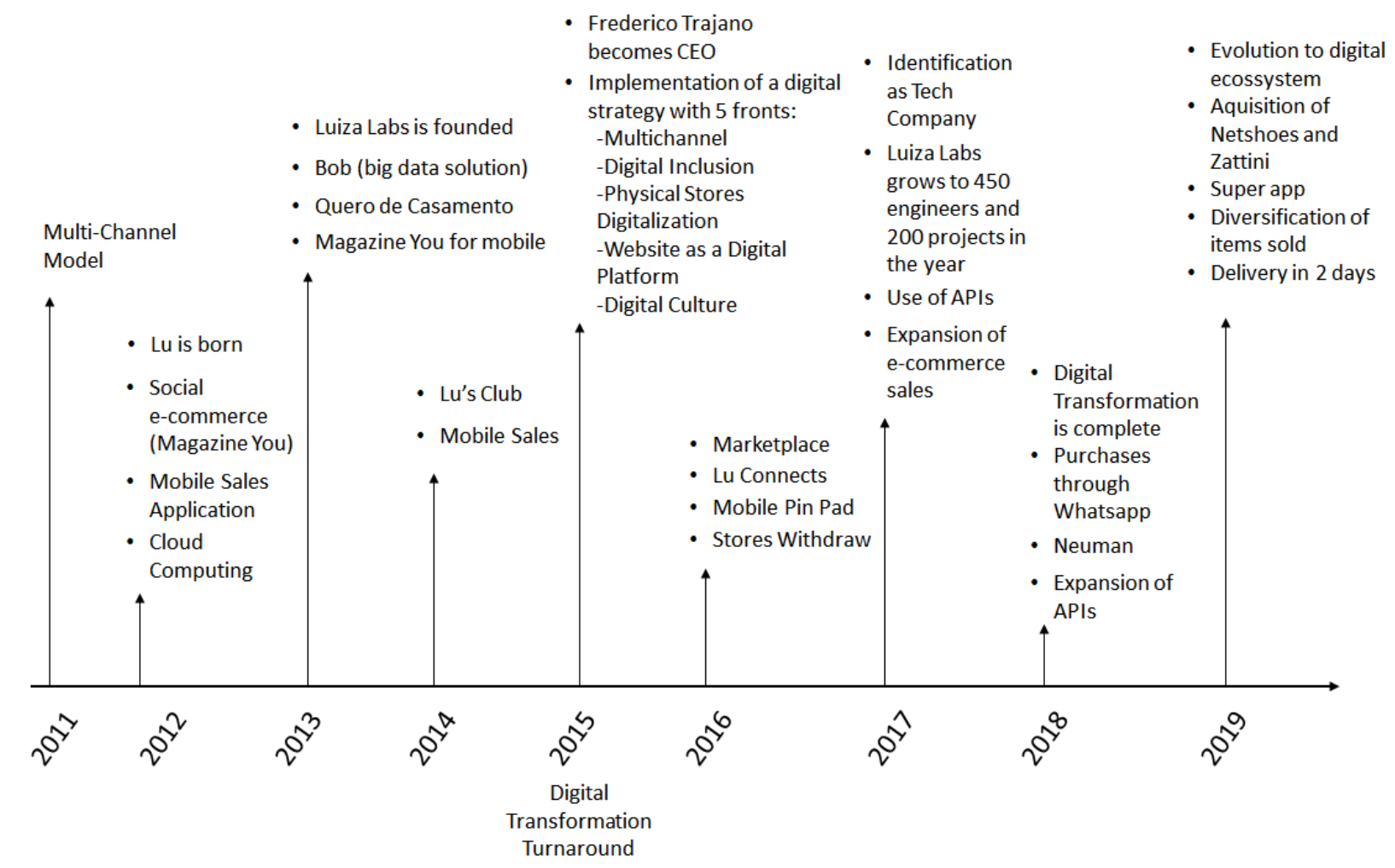

Source: From authors' authority.

Leadership was also a central point in the digital transformation of Luiza Magazine. Frederico Trajano was responsible for convincing the company of the importance of ecommerce and implementing it in Magazine Luiza in 2001 (Barbieri, 2014). Mr. Trajano also supported the creation of Luiza Labs (dos Santos, 2016) and was responsible for the implementation of the company's digital strategy in 2015, the year when he became a CEO.

It was only in 2015, when the digital strategy of the company was released (Figure 5), that these transformational initiatives became part of the company's strategy. Luiza Labs, for example, was an IT bimodal model for developing innovative projects but was not associated with a broader strategy until it became part of the digital culture pillar. Similar to the digital character Lu, even though it was derived from a strategic pillar of the company, the human relationship present in physical stores, in 2012, was announced in the Annual Report merely in the e-commerce section of the report, with no mention of the human relationship. In 2015, it was integrated into the digital inclusion strategic pillar. 
The leadership of Frederico Trajano was recognized by the Gartner Group as an example of "use of a digital platform to overcome disruption" and as an early adopter of the multimodal model of IT management (Meirelles, 2021).

\section{Discussion}

\subsection{Digital transformation versus digital optimization}

As Gartner defines it, companies can opt for digital transformation or digital optimization strategies (Proctor et al., 2019). In Luiza Magazine, for a moment there were mixed initiatives; the company had digital initiatives to improve operational efficiencies, such as Mobile Sales, Mobile Assembler and Mobile Stockist, but it also had transformational initiatives such as Lu, Bob, Magazine You, and other initiatives that were not part of a digital transformation strategy but rather isolated initiatives.

Smart machines, such as digital cognitive systems (Lu), are able to gain human capabilities through biological cognitive systems and are already able to recognize voices, process natural language and interact and learn in physical systems through vision, smell, touch, motor control for mobility and other kinds of senses. In this way, this machinery provides a much faster outcome once it can do a much better job than human beings without fatigue, such as recognition of patterns, performing rule-based analysis from metadata databases and solving structured and unstructured problems. In these terms, the business process and all industries are about to be transformed even further (Demirkan, Spohrer \& Welser, 2016).

They affirm that organizations must identify their business objectives and focus on some areas to approach digital transformation before expanding it to other departments and parts of the company. Executives must understand and learn how to become more flexible and agile, reduce costs and increase quality concerning digital solutions. In addition, personnel must understand the new business models, technologies paradigms, cultural evolutions and management practices that foster innovation in a digital-centric business.

Thus, in 2015 , there was a clear intention to transform the company, not only optimize it. A new cycle in company history began: the digital transformation cycle. A digital transformation strategy was elaborated with five pillars: multichannel model, digital inclusion, physical stores digitalization, transformation of the website into a digital platform and digital culture. There are similarities between these pillars and Vial's building blocks of the digital transformation process (Vial, 2019). First, the multichannel model and the transformation of the website in a digital platform can be seen as disruptions enabled by digital 
technologies, and no other Brazilian retail company applied these concepts in as structured a way as Luiza Magazine. Second, the disruptions became a holistic strategic change - the digital transformation cycle. Third, these changes were related to company culture, leadership, and efficiency. However, different from Vial's framework, in Luiza Magazine, leadership and culture were closely linked to the use of digital technologies to fuel disruptions and not just satellite aspects affecting changes in value creation.

Regarding the duration of the digital transformation, clear statements in the digital transformation strategy about the speed of the transformation process were not identified. The company stated in 2016 that it was a continuous process, without a "finish line", aligned with the concepts of Matt, Hess, and Benlian (2015) and Vial (2019). Contradictorily, in 2018, the company stated that the digital transformation process had ended, and it was now a tech company, similar to Bharadwaj et al.'s (2013) concept of a digital business strategy. In 2019, the company announced a new phase of evolving to a digital ecosystem for retail. These declarations suggest that the digital transformation of a company is a phased process, more than a continuous process or one huge and unique process, as Berghaus and Back (2016) argue.

It seems that Magazine Luiza is moving toward innovation management, where the technology is intrinsic to the organization. Hidalgo and Albors (2008) indicate that innovation management is something that can be built into a firm's culture, where the main goal is to have a transformation from a group of people working into a team highly capable and energized where they are constantly looking forward to new and better ways of getting the job done. However, this is not an easy task. They also affirm that a great difficulty in achieving this stage is because many organizations do not have the capacity to identify innovations and introduce them into regular production and daily processes.

\subsection{Digital technologies and innovation}

Digital technologies can be defined as combinations of information, computing, communication, and connectivity technologies (Bharadwaj et al., 2013), aggrouping legacy and new technologies. However, the study of digital transformation can be misguided by focusing on recent technologies alone, such as social media, mobile, analytics and embedded devices (Fitzgerald et al., 2014; Vial, 2019).

In Luiza Magazine, recent technologies such as big data (Bob) and cloud are being adopted, which suggests that the company is alert to the use of new technologies. However, these approaches appear more as an adoption than as true innovations. The main innovations of 
the company are based on technologies at the plateau of the production stage (as defined by Gartner) but approached in different ways. Magazine You, a social commerce initiative, is an e-commerce variant mixed with social networks. The Lu character was a great innovation that renewed the company's image as a digital company and started as a graphic computing initiative (a legacy technology) that was used to explain product characteristics to customers. It was so successful that later it also became a chatbot, used in customer service and communications.

The usage and provision of APIs became the true building block for digital transformation through the rapid prominence of APIs. It allowed points of digital control that set the terms for which data and services could be spread or shared in an efficient way over the internet. (Demirkan, Spohrer \& Welser, 2016). Building blocks can be understood as automatization, digital accesses, interconnectivity and exchange, artificial intelligence, data, and user experience (Wißotzki \& Sandkuhl, 2017). Companies that want to have a central role in the digital ecosystem must consider offering APIs in their segments to become key enablers of digital capabilities, providing a differentiated value proposition (Demirkan, Spohrer \& Welser, 2016). This is exactly what Magazine Luiza is doing by using this technology to become one of the most technological companies in Brazil.

This demonstrates that new technology applications are not innovations by themselves in the digital transformation strategy, but when mixed and integrated with older technologies in innovative ways, they can make companies differentiate themselves and be more competitive. It is also important to note that what characterized the digital transformation of Magazine Luiza was not only digital innovation, as conceptualized by Nambisan et al. (2017), but the company's culture and the change in leadership and in the company's overall strategy, which drove the creation of digital innovations.

Although the use of new technologies does not imply that the company will generate innovation, when Magazine Luiza announced its digital transformation strategy in 2015, the company started to evolve the innovations it had already developed by mixing them with new technologies. Lu becoming a chatbot is an example. The transformation of e-commerce in a digital platform, grouping other innovations of the company such as Magazine You and Quero de Casamento, is another example. These innovations were added to Época Cosméticos and ecommerce to create a digital platform, which later incorporated the marketplace model. A factor of digital transformation that was not explored in theoretically, is the role of connectivity in the digital transformation strategy of companies. Although there is extensive literature on digital economics and the connectivity of people and institutions, this theme was not properly explored 
when digital transformation strategies were studied. In Magazine Luiza's case, connectivity among everything appears to be fundamental to the digital transformation strategy, not only among companies and customers (e.g., Magazine You) but also between company initiatives, company channels (multichannel model), customer connectivity (e.g., Wi-Fi in stores) and connectivity with partners and suppliers (e.g., marketplace).

\section{Conclusion}

The digital revolution is transforming the fundamental nature of public and private organizations in a very rapid way in every kind of industry, such as health care, agriculture, finance, logistics and s transportation, education, manufacturing, telecommunications, energy, and water treatment, among others.

This transformation provides a means to improve the efficiency, effectiveness, sustainability and innovativeness of products and services once it offers (i) new types of service provisions, such as Uber, Airbnb, Kindle, Google, and Facebook; (ii) automated activities through cognitive assistants such as Magazine Luiza Lu, Apple Siri, IBM Watson, Microsoft Cortana, Amazon Echo and others; (iii) industrialization which improves existing services separating traditional production from customer contact enhancing storability, transportability and access to knowledge-based services such as tax software, online classes or patents; (iv) customer experience as an outcome targeted for experience optimization, process improvements and cost savings; (v) new value propositions and governance mechanisms such as Apple iTunes, online broker systems, auction technology and others; (vi) cost reductions such as fully automated call centers and customer support; (vii) improvement in service quality perceived by the customer such as customized or standardized products and services; (viii) integration between customers and suppliers such as self-service education, business-tobusiness solutions, commoditization of business processes, applications and technologies; and (ix) delivery of knowledge-intensive professions to labor-intensive employment.

All of this has the main goal of improving productivity and creativity within organizations and their employees through decision-making, connectivity, innovation, and augmentation, which enables higher levels of sharing information and knowledge through the use of these ICTs (Demirkan, Spohrer \& Welser, 2016).

The digital transformation of Magazine Luiza resulted in a 43,000\% increase in the market value of the company, aligned with increasingly better results, suggests that technology has the potential to change the strategy of a company and make it succeed, corroborating 
Bharadwaj's perspective that IT cannot be treated merely as a support area as it was years ago (and still is for many companies), but rather should be part of a company's strategy. As observed by Hinings, Gegenhuber and Greenwood (2018, p. 55), "digital transformation is a combination of effects from different digital innovation sources and it's about new kind of actors, structures, practices, values and beliefs that change, threaten, replace or complement existing rules within organizations, ecosystems, industries and fields". This implies a radical organizational change.

We also observe in Magazine Luiza's case that the implementation of a digital transformation is an evolutionary process that begins with small initiatives that grow, evolve and merge into great innovations.

Culture and leadership were essential to the implementation of the digital transformation in Magazine Luiza's case. The use of a bimodal IT structure (Luiza Labs), where a team focused on developing innovation, was a very successful initiative from the company. Adams, Bessant, and Phelps (2006) affirm that organizations that are more likely to make innovation truly happen are those where the chief executives have a clear vision of their operations and have good knowledge about the direction of organizational change and creativity. Additionally, senior managers are responsible for communicating, spreading, and developing the innovation view, adopting it first and supporting others in becoming increasingly willing to engage in organizational change.

It is also important to note that digital transformation is not just about technology; the Lu character, for example, was created from the company culture of offering warm treatment to customers in the physical stores. Business models and innovative technologies that have proven to be successful are those that are aligned with existing values, alongside refocusing the organization's core values and strategies. Innovation brings great opportunities but also complex systems. It requires that companies ensure that the right processes are in place to be managed into the complex environment that digital innovation introduces (vom Brocke et al., 2017).

In this way, to become successful, digital business models require a high level of agility in organizations; such models are only recommended if the change in effect can be determined at any point in time. Digital business models create entirely new products and services, leading them to new processes and new operational procedures and redefining them completely in the organization. In this case, firms need to rethink and upgrade their managerial staff and approaches to be able to quickly transform into the digital environment. Knowledge is key to have success in digital transformation, which also requires business model management, 
capability management and enterprise architecture management (Wißotzki \& Sandkuhl, 2017), which were how Magazine Luiza conducted its entire program of digital transformation and innovation.

\subsection{Contributions and limitations}

This study contributes to the literature by analyzing empirical data on the pillars that support the implementation of digital transformation in an organization, which can be used as input to theory development on digital transformation. The study also highlights important aspects that are not properly studied in the literature about digital transformation, such as the importance of connectivity and the perspective that innovation in the digital age does not necessarily involve recent technologies.

Although this study provides valuable insights for further studies on the main aspects of the digital transformation of companies, the utilization of secondary data only may not offer the whole context of a situation. Thus, our analysis may not comprehend all or provide a true understanding of the main aspects of the digital transformation of companies.

We also assume the data the company released are reliable and that the increases in Magazine Luiza stock were due to the digital transformation of the company, based on commentaries from specialists.

The criteria for the selection of Magazine Luiza for this case study was its success in its digital transformation. It is necessary to study digital transformation in companies with different outcomes to verify the applicability of this study's findings.

It is important to note that we did not have access to the 2014 annual report from the company website due to an error on the website. Although other materials were analyzed from the company's website, they do not guarantee the same amount and quality of information as that available in an annual report.

Little information was found in the analyzed data about projects that failed or the difficulties faced by the teams that participated in the digital initiatives. These aspects may be important to a successful digital transformation; they were not properly covered in this study and are an interesting opportunity for future research. 


\section{References}

Adams, R., Bessant, J., \& Phelps, R. (2006). Innovation management measurement: A review. International journal of management reviews, 8(1), 21-47. https://doi.org/10.1111/j.1468-2370.2006.00119.x

ADVFN. (2020). Histórico MAGAZ LUIZA ON - MGLU3. Retrieved Jan 19, 2020, from https://br.advfn.com/bolsa-de-valores/bovespa/magaz-luiza-onMGLU3/historico/mais-dados-historicos

Agarwal, R., Gao, G., DesRoches, C., \& Jha, A. K. (2010). Research commentary-The digital transformation of healthcare: Current status and the road ahead. Information Systems Research, 21(4), 796-809. https://doi.org/10.1287/isre.1100.0327

Albertin, A. L., \& Albertin, R. M. d. M. (2012). Dimensões do uso de tecnologia da informação: um instrumento de diagnóstico e análise. Revista de Administração Pública, 46(1), 125-151.

Ayres, R. U., \& Williams, E. (2004). The digital economy: Where do we stand? Technological Forecasting and Social Change, 71(4), 315-339. https://doi.org/10.1016/j.techfore.2003.11.001

Barbieri, C. (2014). Ele chegou lá "fazendo medo", Época Negócios. Retrieved from https://epocanegocios.globo.com/Informacao/Visao/noticia/2014/03/ele-chegou-lafazendo-medo.html

Bartis, E., \& Mitev, N. (2008). A multiple narrative approach to information systems failure: a successful system that failed. European Journal of Information Systems, 17(2), 112 124. https://doi.org/10.1057/ejis.2008.3

Berghaus, S., \& Back, A. (2016). Stages in Digital Business Transformation: Results of an Empirical Maturity Study. Paper presented at the MCIS.

Bharadwaj, A., El Sawy, O. A., Pavlou, P. A., \& Venkatraman, N. (2013). Digital business strategy: toward a next generation of insights. MIS quarterly, 471-482. https://doi.org/10.25300/MISQ/2013/37:2.3

Bharadwaj, A. S. (2000). A resource-based perspective on information technology capability and firm performance: an empirical investigation. MIS quarterly, 169-196. http://dx.doi.org/10.2307/3250983

Burke, R. R. (1997). Do you see what I see? The future of virtual shopping. Journal of the Academy of Marketing Science, 25(4), 352-360.

Cain, M., \& Waller, G. (2018). Closing the Digital Dexterity Gap in Digital Business Strategies. Retrieved Jan 26, 2020, from https://www.gartner.com/document/3880765

Capucci, R., \& Castro, L. (2017). Brasil vive a pior recessão da história, G1. Retrieved from http://g1.globo.com/jornal-hoje/noticia/2017/03/brasil-vive-pior-recessao-dahistoria.html 
Castellar, G. B., \& Querido, M. F. R. (2020). Rumo ao topo: O Impacto da Transformação Digital no Valor de Mercado do Magazine Luiza. International Symposium on Project Management, Innovation and Sustainability (SINGEP) Conference 2020, São Paulo, Brazil.

Cope, N. (1996). Retail in the digital age: Bowerdean.

Davenport, T. H., \& Westerman, G. (2018). Why so many high-profile digital transformations fail. Harvard Business Review, 9, 15.

Demirkan, H., Spohrer, J. C., \& Welser, J. J. (2016). Digital innovation and strategic Transformation. IT Professional, 18(6), 14-18.

dos Santos, A. L. (2016). Revolução digital em uma empresa de meio século. GV Executivo, 15.

Dos Santos, B. L., Peffers, K., \& Mauer, D. C. (1993). The impact of information technology investment announcements on the market value of the firm. Information Systems Research, 4(1), 1-23. https://doi.org/10.1287/isre.4.1.1

Dreyfuss, C., \& Toledo, B. (2019). 2019 CIO Agenda: A Brazil Perspective. Retrieved Jan 26, 2020, from https://www.gartner.com/document/3905896?ref=solrAll\&refval=230221979\&qid=92 d5db8daa5ca8dac70d0

Drnevich, P. L., \& Croson, D. C. (2013). Information technology and business-level strategy: toward an integrated theoretical perspective. MIS quarterly, 483-509. http://dx.doi.org/10.25300/MISQ/2013/37.2.08

Ebneyamini, S., \& Sadeghi M. M. R. (2018). Toward Developing a Framework for Conducting Case Study Research. International Journal of Qualitative Methods, 17(1), 160940691881795. doi: http://dx.doi.org/10.1177/1609406918817954

Eisenhardt, K. M. (1989), Building theories from case study research, Academy of Management Review, 1989, vol. 14. No. 4, 532-550.

Fichman, R. G., Dos Santos, B. L., \& Zheng, Z. (2014). Digital innovation as a fundamental and powerful concept in the information systems curriculum. MIS quarterly, 38(2), 329-A315.

Fitzgerald, M., Kruschwitz, N., Bonnet, D., \& Welch, M. (2014). Embracing digital technology: A new strategic imperative. MIT Sloan Management Review, 55(2), 1.

Framingham, M. (2019). Businesses Will Spend Nearly \$1.2 Trillion on Digital Transformation This Year as They Seek an Edge in the Digital Economy, According to a New IDC Spending Guide. Retrieved Jan 26, 2020, from https://www.idc.com/getdoc.jsp?containerId=prUS45027419

Gewald, H., Wang, X., Weeger, A., Raisinghani, M. S., Grant, G., Sanchez, O., \& Pittayachawan, S. (2017). Millennials' attitudes toward IT consumerization in the 
workplace. Communications of the ACM, 60(10), 62-69. https://doi.org/10.1145/3132745

Gu, W., \& Surendra, G. (2004). The effect of organizational innovation and information technology on firm performance. Available at SSRN 1404689.

Haffke, I., Kalgovas, B., \& Benlian, A. (2017). Options for Transforming the IT Function Using Bimodal IT. MIS Quarterly Executive, 16(2).

Hall, B. H. (1999). Innovation and market value.

Hanelt, A., Bohnsack, R., Marz, D., \& Antunes Marante, C. (2021). A systematic review of the literature on digital transformation: insights and implications for strategy and organizational change. Journal of Management Studies, 58(5), 1159-1197. https://doi.org/10.1111/joms.12639

Henderson, J. C., \& Venkatraman, H. (1999). Strategic alignment: Leveraging information technology for transforming organizations. IBM systems journal, 38(2.3), 472-484.

Hess, T., Matt, C., Benlian, A., \& Wiesböck, F. (2016). Options for formulating a digital transformation strategy. MIS Quarterly Executive, 15(2).

Hidalgo, A., \& Albors, J. (2008). Innovation management techniques and tools: a review from theory and practice. R\&d Management, 38(2), 113-127. https://doi.org/10.1111/j.1467-9310.2008.00503.x

Hill, N., \& Govekar, M. (2019). Adopt I\&O Key Performance Indicators to Deliver Digital Business Value. Retrieved Jan 26, 2020, from https://www.gartner.com/document/3913293

Hinings, B., Gegenhuber, T., \& Greenwood, R. (2018). Digital innovation and transformation: An institutional perspective. Information and Organization, 28(1), 52-61. https://doi.org/10.1016/j.infoandorg.2018.02.004

Horlach, B., Drews, P., \& Schirmer, I. (2016). Bimodal IT: Business-IT alignment in the age of digital transformation. Multikonferenz Wirtschaftsinformatik (MKWI), 1417-1428.

Hox, J. J., \& Boeije, H. R. (2005). Data collection, primary versus secondary.

Kahil, G. (2011). Ações da Magazine Luiza sobem em estreia na bolsa, Exame. Retrieved from https://exame.abril.com.br/mercados/acoes-da-magazine-luiza-sobem-em-estreiana-bolsa/

Karimi, J., \& Walter, Z. (2015). The role of dynamic capabilities in responding to digital disruption: A factor-based study of the newspaper industry. Journal of Management Information Systems, 32(1), 39-81. https://doi.org/10.1080/07421222.2015.1029380

Kojikovski, G. (2014). Empresas de e-commerce vão melhorar a entrega? Exame. Retrieved from https://exame.abril.com.br/revista-exame/e-hora-de-entregar/ 
Kraus, S., Schiavone, F., Pluzhnikova, A., \& Invernizzi, A. C. (2021). Digital transformation in healthcare: Analyzing the current state-of-research. Journal of Business Research, 123, 557-567. https://doi.org/10.1016/j.jbusres.2020.10.030

LeHong, H., \& Waller, G. (2018). Digital Business Ambition: Transform or Optimize? Retrieved Jan 26, 2020, from https://www.gartner.com/document/3753470

Madureira, D. (2019). De corpo e alma: as lições de Marcelo Silva, o conselheiro que fez a ponte na gestão do Magazine Luiza, Seu Dinheiro. Retrieved from https://www.seudinheiro.com/2019/governanca-corporativa/de-corpo-e-alma-aslicoes-de-marcelo-silva-o-conselheiro-que-fez-a-ponte-na-gestao-do-magazine-luiza/

Magazine Luiza. (2011). J.P. Morgan 5th Annual Brazil Check Up. Retrieved from https://ri.magazineluiza.com.br/ShowApresentacao/Apresentacao-Institucional---J-P-Morgan-5o-Annual-Brazil-Check-Up?=amBndgoAAbt8Sf33XlfXBQ==

Magazine Luiza. (2012). $7^{a}$ Conferência Anual de CEO da América Latina. Retrieved from https://ri.magazineluiza.com.br/ShowApresentacao/7a-Conferencia-Anual-de-CEOda-America-Latina?=h51/QM3Nct8PINptcKy+1Q==

Magazine Luiza. (2012). Internet Day - Magazine Luiza. Retrieved from https://ri.magazineluiza.com.br/ShowApresentacao/InternetDay?=cXGAVcJTI/vv91ZLqBXMSg==

Magazine Luiza. (2012). Relatório Anual 2012. Retrieved from https://ri.magazineluiza.com.br/ShowCanal/Download.aspx?Arquivo=IRsCksvOvulvI $\mathrm{RNrKCHzuw}==$

Magazine Luiza. (2012). RELATÓRIO DA ADMINISTRAÇÃO 2012. Retrieved from https://ri.magazineluiza.com.br/ShowCanal/Download.aspx?Arquivo=lgZip656SwZdx K0etsWZcw==

Magazine Luiza. (2013). Relatório Anual e de Sustentabilidade 2013. Retrieved from https://ri.magazineluiza.com.br/ShowCanal/Download.aspx?Arquivo=W4JaYE7MRg pivcJFE6u95 A==

Magazine Luiza. (2013). RELATÓRIO DA ADMINISTRAÇÃO 2013. Retrieved from https://ri.magazineluiza.com.br/ShowCanal/Download.aspx?Arquivo=7YRaVmcev42 awzl3Lgt5sQ==

Magazine Luiza. (2014). ML Day - Frederico Trajano. Retrieved from https://ri.magazineluiza.com.br/Download.aspx?Arquivo=K3/xrB9b8Armn8BTDu0O $\mathrm{VA}==$

Magazine Luiza. (2014). RELATÓRIO DA ADMINISTRAÇÃO 2014. Retrieved from https://ri.magazineluiza.com.br/ShowCanal/Download.aspx?Arquivo=9yx/31XAj6ynL eVWjNh06w== 
Magazine Luiza. (2015). ML Day - Frederico Trajano. Retrieved from https://ri.magazineluiza.com.br/Download.aspx?Arquivo=gKEN3wLp3aZ1wUdRrhOs $\mathrm{ig}==$

Magazine Luiza. (2015). Movimento \#abraceonovo. Retrieved from https://ri.magazineluiza.com.br/Download.aspx?Arquivo=bG2mKN6d9+Pykt6jAnHw $\mathrm{JA}==$

Magazine Luiza. (2015). RELATÓRIO DA ADMINISTRAÇÃO 2015. Retrieved from https://ri.magazineluiza.com.br/ShowCanal/Download.aspx?Arquivo=zRRKJ4sUZHh MCILLfnmV+g==

Magazine Luiza. (2015). Relatório Integrado 2015. Retrieved from https://ri.magazineluiza.com.br/ShowCanal/Download.aspx?Arquivo=jYtxM2XFH25j Tc9Q1ATtfg==

Magazine Luiza. (2016). ML Day. Retrieved from https://ri.magazineluiza.com.br/Download.aspx?Arquivo=RB+PBEus60wvsL57Jk+N $\mathrm{TQ}==$

Magazine Luiza. (2016). RELATÓRIO DA ADMINISTRAÇÃO 2016. Retrieved from https://ri.magazineluiza.com.br/ShowCanal/Download.aspx?Arquivo=6Q50Bu+Jaril6 NwXzJ0a7A==

Magazine Luiza. (2016). Relatório Integrado 2016. Retrieved from https://ri.magazineluiza.com.br/Download.aspx?Arquivo=g/+8Ojwqr0h2dUxayk2p0w $==$

Magazine Luiza. (2017). ML Day 2017. Retrieved from https://ri.magazineluiza.com.br/Download.aspx?Arquivo=IazuzcRLqRCcuIsBBc9Wf $\mathrm{A}==$

Magazine Luiza. (2017). RELATÓRIO DA ADMINISTRAÇÃO 2017. Retrieved from https://ri.magazineluiza.com.br/Download.aspx?Arquivo=cdkvnF15k4eB9rdMeRcYi $\mathrm{Q}==$

Magazine Luiza. (2017). Relatório Integrado 2017. Retrieved from https://ri.magazineluiza.com.br/Download.aspx?Arquivo=/lVHvpl2FQ18P0BAunNKA $\mathrm{w}==$

Magazine Luiza. (2018). ML Day. Retrieved from https://ri.magazineluiza.com.br/Download.aspx?Arquivo=qVep2sBEJz/OSqo3ZOrGE $\mathrm{w}==$

Magazine Luiza. (2018). RELATÓRIO DA ADMINISTRAÇÃO 2018. Retrieved from https://ri.magazineluiza.com.br/Download.aspx?Arquivo=oR2RKDVXnKPcO18rhxiz $\mathrm{sA}==$ 
Magazine Luiza. (2019). Magalu Day 2019. Retrieved from https://ri.magazineluiza.com.br/ShowApresentacao/Apresentacao-ML-Day2019?=VDyAuvo9DW5GWU4ihzjz4A==

Matt, C., Hess, T., \& Benlian, A. (2015). Digital transformation strategies. Business \& Information Systems Engineering, 57(5), 339-343. https://doi.org/10.1007/s12599-015-04015

Meirelles, F. S. (2021). Pesquisa Anual Uso de TI nas Empresas. FGVcia - Centro de Tecnologia de Informação Aplicada da FGV-EAESP, 32a edição, 2021 www.fgv.br/cia/pesquisa

Mello, B. (2011). Magazine Luiza cria venda direta pelas redes sociais, Exame. Retrieved from https://exame.abril.com.br/marketing/magazine-luiza-cria-venda-direta-pelasredes-sociais/

Mithas, S., Tafti, A., \& Mitchell, W. (2013). How a firm's competitive environment and digital strategic posture influence digital business strategy. MIS Quarterly, 511-536. http://dx.doi.org/10.25300/MISQ/2013/37.2.09

Nama. (2018). Lu, o chatbot da Magazine Luiza que é queridinho do público. Retrieved from https://www.nama.ai/recursos/cases/magalu\#download

Nambisan, S., Lyytinen, K., Majchrzak, A., \& Song, M. (2017). Digital Innovation Management: Reinventing innovation management research in a digital world. Mis Quarterly, 41(1). http://doi.org/10.25300/MISQ/2017/41:1.03

Nwaiwu, F. (2018). Review and comparison of conceptual frameworks on digital business transformation. Journal of Competitiveness, 10(3), 86. https://doi.org/10.7441/joc.2018.03.06

Nwankpa, J. K., \& Roumani, Y. (2016). IT capability and digital transformation: a firm performance perspective. Paper presented at the International Conference on Information (ICIS).

Nylén, D., \& Holmström, J. (2015). Digital innovation strategy: A framework for diagnosing and improving digital product and service innovation. Business Horizons, 58(1), 5767.

Olesen, K., \& Myers, M. D. (1999). Trying to improve communication and collaboration with information technology. Information Technology \& People. https://doi.org/10.1108/09593849910301621

Olivon, B. (2013). Ações do Magazine Luiza sobem após nova aquisição, Exame. Retrieved from https://exame.abril.com.br/mercados/acoes-do-magazine-luiza-sobem-apos-novaaquisicao/

Pantano, E. (2014). Innovation drivers in retail industry. International Journal of Information Management, 34(3), 344-350. https://doi.org/10.1016/j.ijinfomgt.2014.03.002. 
Paulo, F. d. S. (2019). Magazine Luiza se valoriza mais de $1.000 \%$ desde abertura de capital, Folha de São Paulo. Retrieved from https://www1.folha.uol.com.br/mercado/2019/04/magazine-luiza-se-valoriza-mais-de1000-desde-abertura-de-capital.shtml

Paulo, I. S. (2014). Preços ainda são problemas na megapromoção: segundo internautas, sites mentem sobre descontos, iG. Retrieved from https://economia.ig.com.br/2014-1128/black-friday-tem-sites-em-manutencao-filas-de-espera-e-lentidao.html

Piccinini, E., Gregory, R. W., \& Kolbe, L. M. (2015). Changes in the producer-consumer relationship-towards digital transformation. Changes, 3(4), 1634-1648.

Proctor, P., Smith, M., Anderson, J., \& Sampath, S. (2019). The Gartner Digital Business Value Model: A Framework for Measuring Business Performance. Retrieved Jan 26, 2020, from https://www.gartner.com/document/3970428

Rai, A., \& Tang, X. (2014). Research commentary-information technology-enabled business models: A conceptual framework and a coevolution perspective for future research. Information Systems Research, 25(1), 1-14. https://doi.org/10.1287/isre.2013.0495.

Reuters. (2015). Magazine Luiza pode avaliar fechar capital, diz presidente do conselho, G1. Retrieved from http://g1.globo.com/economia/negocios/noticia/2015/12/magazineluiza-pode-avaliar-fechar-capital-diz-presidente-do-conselho20151210134506779367.html

Ross, J. (2014). Designing your business for the digital economy. Retrieved Jan 26, 2020, from http://www.oracle.com/technetwork/articles/entarch/oeea-ross-2365369.html

Scardovi, C. (2017). Digital transformation in financial services (Vol. 236): Springer.

Schramm, W. (1971). Notes on Case Studies of Instructional Media Projects.

Schumpeter, J. A. (1934). The Theory of Economic Development. Cambridge, MA: Harvard University Press.

Scopus. (2020). Retrieved Jan 26, 2020, from https://www.scopus.com/home.uri

Setia, P., Setia, P., Venkatesh, V., \& Joglekar, S. (2013). Leveraging digital technologies: How information quality leads to localized capabilities and customer service performance. MIS quarterly, 565-590. http://doi.org/10.25300/MISQ/2013/37.2.11

Sia, S. K., Soh, C., \& Weill, P. (2016). How DBS Bank Pursued a Digital Business Strategy. MIS Quarterly Executive, 15(2).

Soh, C., Yeow, A., Goh, Q., \& Hansen, R. (2019). Digital Transformation: Of Paradoxical Tensions and Managerial Responses.

Tapscott, D. (1996). The digital economy: Promise and peril in the age of networked intelligence (Vol. 1): McGraw-Hill New York. 
Tapscott, D. (2014). The Digital Economy: Rethinking Promise and Peril in the Age of Networked Intelligence (Vol. 2): McGraw-Hill New York.

Verhoef, P. C., Broekhuizen, T., Bart, Y., Bhattacharya, A., Dong, J. Q., Fabian, N., \& Haenlein, M. (2021). Digital transformation: A multidisciplinary reflection and research agenda. Journal of Business Research, 122, 889-901. https://doi.org/10.1016/j.jbusres.2019.09.022.

Vial, G. (2019). Understanding digital transformation: A review and a research agenda. The Journal of Strategic Information Systems. https://doi.org/10.1016/j.jsis.2019.01.003.

vom Brocke, J., Fay, M., Schmiedel, T., Petry, M., Krause, F., \& Teinzer, T. (2017). A journey of digital innovation and transformation: The case of Hilti. In Shaping the Digital Enterprise (pp. 237-251). Springer, Cham. https://doi.org/10.1007/978-3-31940967-2_12.

Winkelhake, U., Winkelhake, \& Schilgerius. (2018). Digital Transformation of the Automotive Industry: Springer.

Wißotzki, M., \& Sandkuhl, K. (2017, November). The digital business architect-towards method support for digital innovation and transformation. In IFIP Working Conference on The Practice of Enterprise Modeling (pp. 352-362). Springer, Cham. https://doi.org/10.1007/978-3-319-70241-4_24

Yin, R. K. (2017). Case study research and Applications: Design and methods (applied social research methods): Sage publications Thousand Oaks, CA.

Yoo, Y., Henfridsson, O., \& Lyytinen, K. (2010). Research commentary - the new organizing logic of digital innovation: an agenda for information systems research. Information Systems Research, 21(4), 724-735. https://doi.org/10.1287/isre.1100.0322 